\title{
A Critical Analysis on Hospital Waste Management at Bandipur Hospital, Bandipur, Tanahu District, Nepal
}

\author{
Ghimire HP ${ }^{1 *}$, Dhungana $\mathrm{A}^{2}$ \\ 'Assistant Professor, ${ }^{2}$ Lecturer, Department of Community Medicine, \\ Gandaki Medical College \& Teaching Hospital, Pokhara, Nepal
}

\begin{abstract}
Background: Hospitals generate large volumes of wastes as a byproduct of a variety of health services and procedures carried out such as surgery, dressing of the wounds, dialysis, deliveries, laboratory and dental procedures, postmortem procedures etc. Such a waste may be infectious or non-infectious. If such a waste is not collected, transported and disposed off, it not only results in causation of 'Hospital Acquired Infections" but also poses a major public health hazard by causing pollution of air, water and soil.
\end{abstract}

Objective: This study objective was to critically analyze current waste management system in Bandipur Hospital, Tanahu District, Nepal and critically review the findings.

Methods: For the critical analysis on waste management, literature review on hospital waste management was done. The techniques used for critical analysis were observation using observation checklist and interview with hospital manager, doctors, staff nurses, and local people living nearby the hospital. Tool of this critical analysis was SWOT analysis.

Results: It can be seen from SWOT analysis that, most of the waste of the hospital is not managed in an appropriate way. Appropriate segregation and disposal of biodegradable and non biodegradable, infectious and non-infectious wastes is important to avoid health hazards caused by poor waste management such as vector borne diseases, pollution of air, water and soil contamination. In Bandipur Hospital, waste disposal is not according to WHO standard. Physical infrastructures do not meet the requirements. Available dustbins are not according to WHO color coding, no basin at Emergency room, no trolley to carry waste and open dumping practice. The reason behind most of these problems is the

\section{Keywords}

Bandipur Hospital,

Hospital waste,

Waste management.

\section{Corresponding author}

${ }^{*}$ Dr. Hari Prasad Ghimire

Assistant Professor,

Department of Community Medicine

Gandaki Medical College \& Teaching

Hospital, Pokhara, Nepal

Email: hari_ghimire77@yahoo.com management of the hospital, staffs of the hospital and the stakeholders who are not giving any attention to proper waste management process. The other reason beyond this is inadequate budget allocation for waste management in the hospital.

Conclusion: If the waste management of the hospital is done properly, environment of the hospital will become clean and hospital can provide quality health services to the patient. For this there is necessity of strong committment from the hospital management, the hospital staffs, hospital development committee and the Government. 


\section{INTRODUCTION}

Hospital waste is a special type of waste produced in small quantities carrying a high potential of infection and injury. Inadequate and improper handling may have serious public health consequences and a significant impact on the environment ${ }^{1}$. Hospital waste management means the management of waste produced by hospitals using techniques that will check the spread of diseases ${ }^{2}$. In developing countries, awareness regarding hospital waste management in terms of its segregation, collection, storage, transportation and disposal is lacking ${ }^{3-6}$. Hospital waste refers to all waste generated, discarded and not intended for further use in hospital. Biomedical waste is any solid fluid and liquid or liquid waste including its container and any intermediate products which is generated during the diagnosis, treatment or immunization of human beings or animals, in research pertaining there to or in the production or testing of biological or animal waste from slaughter houses or any other similar establishment. In hospital, it comprises of $15 \%$ of total hospital waste ${ }^{7-12}$.

\section{Classification of hospital waste}

1. General waste: It is non-hazardous to human beings. Largely composed of domestic or household type of waste. E.g. kitchen waste, papers, wrappers, plastics etc.

2. Pathological waste: It is hazardous waste consisting of tissues, organs, body parts, human fetus, blood and body fluids etc.

3. Infectious waste: It is hazardous waste containing pathogens in sufficient quantity that could cause disease. E.g. culture and stocks of infectious agents from laboratories, waste from surgery and infectious patients.

4. Sharps: Material causing the person a cut or puncture of the skin. Eg. Broken glass, needle, nail, blade, and scalpel etc.

5. Pharmaceutical waste: Includes pharmaceutical products, drugs and chemicals that have spilled, returned from ward, outdated or contaminated.

6. Chemical waste: Comprises of discarded solid, liquid and gases chemicals. E.g. Cleaning, housekeeping and disinfecting product.

7. Radioactive waste: Includes solid liquid and gases waste that is contaminated with radio nucleoids and generated from in vitro of body tissues and fluids, in vivo body organ imaging and tumor localization.

8. Genotoxic waste: Waste containing substances with genotoxic properties E.g. waste containing cytotostatic drugs (often used in cancer therapy), genotoxic chemicals.

9. Pressurized containers: Gas cylinders, gas cartridges, aerosol cans.

\section{Rationale of hospital waste management}

Hospital waste management is a part of hospital hygiene and maintenance activities. In fact only biomedical waste is hazardous and when hazardous waste is not segregated at the source of generation and mixed with non-hazardous waste then $100 \%$ waste becomes hazardous. It is essential that health care waste is collected, stored and disposed of in a proper and scientific manner. General hygiene is a prerequisite for good medical waste management in health care institutions. It is also vital that the whole health care institutions be kept clean and on a satisfactory state of hygiene. Bandipur hospital is nearby Bandipur bazaar and the hospital waste is disposed openly and burned down. The hospital is not having separate placental pit and they are burying the placenta under the sand bank. The hospital is not following the system of dumping the waste in dust bins as per the color coding given by WHO. There is lack of segregation practices. Though hospital has sufficient space within its premises for management of wastes, the waste management is poor. For this reason, I felt that the hospital has much room for improvements in terms of management of hospital waste. Hence, I decided to explore the strengths, weaknesses, opportunities and threats regarding the waste management of Bandipur Hospital.

\section{OBJECTIVES}

\section{General objective}

To critically analyze current waste management system in Bandipur Hospital and critically review the findings

Specific objectives

- To identify the infrastructure for waste management in Bandipur Hospital

- To evaluate the quality in terms of its strength and 
weaknesses of waste management by comparing it with a standard

\section{METHODS}

For the critical analysis on waste management literature review on hospital waste management was done. The techniques used for critical analysis were observation using observation checklist and interview with doctors, staff nurses, and local people living nearby the hospital. Method of this critical analysis was SWOT analysis.

\section{RESULTS}

Findings and comparisons

\section{Physical facilities}

There is no incinerator in the hospital. There are no placental pits. There is a dumping site nearby the hospital approximately 50 meter away from the hospital.

\section{Human resources}

There are five sweepers in the hospital which are inadequate for cleaning of the hospital.

\section{Logistics}

Table 1: Waste management logistics in Bandipur hospital

\begin{tabular}{ll}
\hline Infrastructures & Bandipur hospital \\
Placental pits & Absent \\
$\begin{array}{l}\text { Dumping sites } \\
\text { Dustbins for separation of }\end{array}$ & Present \\
waste & Absent \\
Incinerator & Absent \\
Basins & Present but not maintained \\
$\begin{array}{l}\text { Drainage for liquid waste } \\
\text { Tractor for carrying waste to } \\
\text { dumping site }\end{array}$ & Present \\
Color coding containers & Absent \\
\hline
\end{tabular}

As it can be seen from the table that most of the necessary logistics required for the waste management is not available. Tractor for carrying the solid waste from the hospital to the dumping site is absent. Incinerator is absent in the hospital. Liquid waste is managed by disinfecting them first in sodium hypochlorite and then flowed into the wash basin. The dumping site is nearby the market place approximately 50 meter away from the Hospital. Safety box for syringe disposal is not present at all; however, the syringes are cut in the needle cutter and burnt down after use. In the emergency room there are dustbins for the collection of wastes but not color coded and there are no wash basins.

\section{SWOT Analysis Matrix}

Table 2: SWOT matrix for hospital waste management in Bandipur hospital

\begin{tabular}{|c|c|c|c|c|}
\hline Infrastructure & STRENGTH & WEAKNESS & OPPORTUNITY & THREATS \\
\hline Dumping site & Present & $\begin{array}{l}\text { - Quite near to } \\
\text { the hospital } \\
\text { - Not walled } \\
\text { from any side }\end{array}$ & $\begin{array}{l}\text { - Management of safe } \\
\text { and secure area by the } \\
\text { help of community } \\
\text { for management of } \\
\text { healthcare waste }\end{array}$ & $\begin{array}{l}\text { - Community } \\
\text { denial for } \\
\text { help }\end{array}$ \\
\hline Space & Present & $\begin{array}{l}\text { - Inadequate } \\
\text { space } \\
\text { - Lack of ade- } \\
\text { quate fund for } \\
\text { land purchase }\end{array}$ & $\begin{array}{l}\text { - Land can be } \\
\text { managed in } \\
\text { collaboration } \\
\text { with community } \\
\text { people }\end{array}$ & $\begin{array}{l}\text { - Local res- } \\
\text { idents may } \\
\text { not support }\end{array}$ \\
\hline Trolley & & - No trolley & $\begin{array}{l}\text { - Trolley can be } \\
\text { purchased } \\
\text { - Tractor can be } \\
\text { taken on lease }\end{array}$ & \\
\hline Tractor & & - No tractor & $\begin{array}{l}\text { - Tractor can be } \\
\text { purchased or can } \\
\text { be taken on lease }\end{array}$ & \\
\hline $\begin{array}{l}\text { Dustbins and } \\
\text { puncture }\end{array}$ & $\begin{array}{l}\text {-Adequate } \\
\text { dustbins present }\end{array}$ & $\begin{array}{l}\text { - Dustbins are } \\
\text { not according } \\
\text { to WHO color } \\
\text { coding } \\
\text { - Degradable } \\
\text { and non } \\
\text { degradable } \\
\text { waste are not } \\
\text { separated } \\
\text { - Infectious and } \\
\text { non-infectious } \\
\text { waste are not } \\
\text { separated; Not } \\
\text { covered } \\
\text { - Available } \\
\text { dustbins are } \\
\text { not in use } \\
\text { - Puncture } \\
\text { proof contain- } \\
\text { ers are not } \\
\text { present }\end{array}$ & $\begin{array}{l}\text { - WHO color coded } \\
\text { dustbins implementa- } \\
\text { tion can be done } \\
\text { - Staff can be trained } \\
\text { to separate infectious } \\
\text { and non infectious } \\
\text { and degradable and } \\
\text { non degradable waste }\end{array}$ & $\begin{array}{l}\text { - Dustbins } \\
\text { not used } \\
\text { properly by } \\
\text { patient and } \\
\text { visitor due } \\
\text { to lack of } \\
\text { awareness }\end{array}$ \\
\hline Plastic bags & & $\begin{array}{l}\text {-Are not } \\
\text { available }\end{array}$ & $\begin{array}{l}\text { - It can be } \\
\text { purchased }\end{array}$ & \\
\hline $\begin{array}{l}\text { Special } \\
\text { autoclavable } \\
\text { bags }\end{array}$ & & - Not present & $\begin{array}{l}\text { - Can be } \\
\text { purchased }\end{array}$ & \\
\hline $\begin{array}{l}\text { Recording } \\
\text { and reporting }\end{array}$ & & $\begin{array}{l}\text { - Not } \\
\text { present }\end{array}$ & $\begin{array}{l}\text { - Maintenance of } \\
\text { record registers } \\
\text { - Advanced software } \\
\text { for management of } \\
\text { records }\end{array}$ & $\begin{array}{l}\text {-Skilled } \\
\text { manpower } \\
\text { may not be } \\
\text { present to } \\
\text { operate the } \\
\text { software }\end{array}$ \\
\hline
\end{tabular}




\begin{tabular}{|c|c|c|c|c|}
\hline \multicolumn{5}{|l|}{ Equipments } \\
\hline $\begin{array}{l}\text { Autoclave/ } \\
\text { steam } \\
\text { sterilizer }\end{array}$ & - Present & $\begin{array}{l}\text { - Not } \\
\text { used for } \\
\text { sterilizing } \\
\text { waste }\end{array}$ & $\begin{array}{l}\text { - Collaboration with } \\
\text { community \& NGOs } \\
\text { and INGOs to buy } \\
\text { more autoclaves }\end{array}$ & $\begin{array}{l}\text { - Helping } \\
\text { organization } \\
\text { may not be } \\
\text { able to help } \\
\text { consistently }\end{array}$ \\
\hline $\begin{array}{l}\text { Chemical } \\
\text { disinfectants }\end{array}$ & $\begin{array}{l}\text { - Liquid wastes } \\
\text { are disinfected } \\
\text { with sodium- } \\
\text { hypochlorite } \\
\text { solution }\end{array}$ & & & \\
\hline $\begin{array}{l}\text { Needle } \\
\text { destroyer }\end{array}$ & - Present & $\begin{array}{l}\text { - Insufficient } \\
\text { number }\end{array}$ & $\begin{array}{l}\text { - More needle destroy- } \\
\text { ers can be purchased }\end{array}$ & $\begin{array}{l}\text { - Availability } \\
\text { of needle } \\
\text { destroyers } \\
\text { maybe } \\
\text { limited }\end{array}$ \\
\hline \multicolumn{5}{|l|}{ Manpower } \\
\hline Sweepers & - Present & $\begin{array}{l}\text { - Not sufficient } \\
\text { in number Not } \\
\text { trained }\end{array}$ & $\begin{array}{l}\text { - Training of } \\
\text { concerned staff can } \\
\text { be done }\end{array}$ & $\begin{array}{l}\text { - Inadequa } \\
\text { te trainers } \\
\text { andtraining } \\
\text { materials }\end{array}$ \\
\hline $\begin{array}{l}\text { Waste } \\
\text { handlers }\end{array}$ & & - Not present & $\begin{array}{l}\text { - Hiring waste } \\
\text { handlers on contract } \\
\text { basis }\end{array}$ & \\
\hline $\begin{array}{l}\text { Waste } \\
\text { management } \\
\text { committee }\end{array}$ & & - Not present & $\begin{array}{l}\text { - Establishment of } \\
\text { waste management } \\
\text { committee }\end{array}$ & $\begin{array}{l}\text { - Lack of } \\
\text { coordina- } \\
\text { tion among } \\
\text { committee } \\
\text { members }\end{array}$ \\
\hline \multicolumn{5}{|c|}{ Plan \& policies } \\
\hline $\begin{array}{l}\text { Waste } \\
\text { management } \\
\text { policy }\end{array}$ & $\begin{array}{l}\text { - Solid waste } \\
\text { management } \\
\text { policy present } \\
\text { (National level) }\end{array}$ & $\begin{array}{l}\text { - No special } \\
\text { legislation, } \\
\text { guidelines re- } \\
\text { lated to waste } \\
\text { management }\end{array}$ & $\begin{array}{l}\text { - Establishment } \\
\text { of comprehensive } \\
\text { system of healthcare } \\
\text { waste management }\end{array}$ & $\begin{array}{l}\text { - Political } \\
\text { instability }\end{array}$ \\
\hline \multicolumn{5}{|c|}{ Financial issues } \\
\hline $\begin{array}{l}\text { Budget } \\
\text { resources }\end{array}$ & & $\begin{array}{l}\text { - Hospital } \\
\text { income insuf- } \\
\text { ficient Lack of } \\
\text { sufficient fund }\end{array}$ & $\begin{array}{l}\text { - Collaboration } \\
\text { with waste } \\
\text { recyclers }\end{array}$ & $\begin{array}{l}\text { - Chances of } \\
\text { misutilization } \\
\text { of budget }\end{array}$ \\
\hline
\end{tabular}

It can be seen from above tool used as SWOT analysis that, most of the waste of the hospital is not managed in an appropriate way. Appropriate segregation and disposal of biodegradable and non biodegradable, infectious and non-infectious wastes is important to avoid health hazards, and this hospital did not do so. In Bandipur hospital waste disposal is not according to WHO standard. Physical infrastructures do not meet the requirements. Available dustbins are not according to WHO color coding, no basin at Emergency room, no trolley to carry waste and open dumping practice. There is also under utilization of logistics such as dustbins.

\section{DISCUSSION \& CONCLUSION}

Bandipur Hospital has a large catchment area. Due to high patient flow waste produced in the hospital is also in greater amount. Due to poor waste management in the hospital it will create bad effects not only to patients but also to doctors, hospital staffs and the residents nearby the hospital. This can ultimately increase the disease burden in the Tanahu District. The reason behind most of this problem is the management of the hospital, staffs of the hospital and the stakeholders who are not giving any attention. The other reason beyond this is inadequate budget allocation for waste management in the hospital. Similar type of study done in a Teaching hospital in Karachi Shahida Rashid ${ }^{13}$ et al shows that waste management is not done in a proper way where segregation of biodegradable and non-biodegradeable waste was not done. A study done by Choudhary ${ }^{14}$ et al and Paudel ${ }^{15}$ et al showed that health care waste management practice in the hospitals of Nepal were unsatisfactory because of the lack of waste management plan and carelessness of patients, visitors and staffs.

If the waste management of the hospital is done properly, environment of the hospital will become clean and hospital can provide quality health services to the patient. For this there is necessity of strong committment from the hospital management, the hospital staffs, hospital development committee and the government.

\section{Recommendations}

A separate placental pit should be constructed.

Waste management should be done far away from the town of Bandipur.

Dustbins should be maintained according to the WHO coding standards.

All dry refuse from hospital should be burnt in an incinerator.

\section{REFERENCES}

1. Fluke C. Handling hazardous waste.J Health Mater Manage. 1998; 6: 70-3.

2. Mahmood M, Shahab S, Malik R, Azim W. A study of waste generation, collection and disposal in a tertiary hospital. PakJ Med Res. 2001; 40: 13-17.

3. Ather S. Hospital waste management. J Coll Physicians Surg Pak. 2004; 14: 645-6.

4. Hageman JP. Handling, storage, treatment and 
disposal of mixed wastes at medical facilities and academic institutions. Health Phys. 2002; 82 (Suppl): 566-76.

5. PatilAD, Sekhar AV. Healthcare waste management in India. J Environ Manage. 2001; 63: 211-20.

6. Uysal F, Tinmaz E. Medical waste management in Trachea region of Turkey. Waste Manag Res. 2004; 22: 403-7.

7. A.H. Suryakanta. Community Medicine With Recent Advances. $3^{\text {rd }}$ Edition

8. K. Park. Text book of preventive and social medicine. $22^{\text {nd }}$ Edition.

9. Maxcy-Rosenau - Last. Public health and Preventive Medicine. Fifteen Edition

10. MC Gupta, BK Mahajan. A textbook of preventive and social medicine. $3^{\text {rd }}$ Edition.

11. GM Goddar, I Rabbani. Foundations of Community Medicine. $2^{\text {nd }}$ edition.

12. Vidya Ratan. Handbook of preventive and Social Medicine (Community Medicine). Ninth Edition.

13. Shahida Rashid, Saira Iqbal, Lubna A Baig, Kehkashan Mufti. Hospital waste management in a teaching hospital in Karachi. Journal of Pakistan
Medical Association. June 2005; 55(5): 192-5..

14. Choudhary N, Mahato SK, Choudhary S, Bhatia BD. Biomedical waste management in Nepal: A review. https.//www.researchgate.net/ publication 272365105.

15. Paudel R, Pradhan B. Health care waste management practice in a hospital. J Nepal Health Res Counc. 2010; 8: 8690. PMid:21876569 